\title{
Pytania bez odpowiedzi. Krajobrazy Zagłady z perspektywy kulturowej
}

Małczyński, Jacek. Krajobrazy Zagłady. Perspektywa historii środowiskowej. Warszawa: Wydawnictwo Instytutu Badań Literackich PAN, 2018. $248 \mathrm{~s}$.

Wrocławski kulturoznawca Jacek Małczyński w swojej książce doktorskiej już na samym wstępie zaznacza, że jednym $z$ jego postulatów jest, by studia nad Zagładą otworzyć „na historię środowiskową, jak również by włączyć je „w trwające aktualnie debaty na temat zmian klimatu, zrównoważonego rozwoju, wymierania gatunków, klęsk ekologicznych czy związanych z tym migracji klimatycznych" (Małczyński 7). Zagłada jako wydarzenie zaplanowane i przeprowadzone przez ludzi - i, należy dodać, na ludziach - odbywa się bowiem w określonym na początku przez Autora kontekście, jakim jest epoka antropocenu, podczas której to „nie można pisać historii Ziemi, nie uwzględniając mocy sprawczej człowieka" (Małczyński 8).

Odważnie postawiony na samym początku i tak właśnie sformułowany postulat badawczy w kontekście całości lektury Krajobrazów Zagłady może jednak wprowadzić czytelnika w konfuzję: jaki właściwie jest cel czytanej monografii? Jaka jest proponowana przez Autora teoretyczna rama odniesień? W jaki sposób łączy on badania nad Zagładą z badaniami krajobrazowymi, prowadzonymi wszak od kilku lat z perspektywy różnorodnych dyscyplin naukowych? Na ile spójne i przekonujące są argumenty, które wysuwa na podstawie analizy wybranych źródeł? Aby odpowiedzieć na te pytania, należy przyjrzeć się konstrukcji 
książki. Przede wszystkim jest ona napisana zwięźle i unika przesadnego epatowania erudycyjnością. Po kilkudziesięciostronicowym wprowadzeniu, w którym Małczyński przedstawia swój pomysł na historię środowiskową Zagłady - do czego jeszcze powrócę - oraz stan badań, źródła i metody, a także omawia podstawowe pojęcia z zakresu studiów nad krajobrazem, czytelnik otrzymuje trzy różnorodne rozdziały analityczno-interpretacyjne, zwieńczone może aż nazbyt zwięzłym zakończeniem, nieoddającym sprawiedliwości uprzednio zaprezentowanej treści.

Każdy rozdział analityczny napisany jest z nieco innej perspektywy i bazuje na innych źródłach. Pierwszy, pod tytułem Pocztówki z Auschwitz. Idea krajobrazu w Trzeciej Rzeszy, prezentuje badania dotyczące kart pocztowych - przede wszystkim tych, które niemieccy funkcjonariusze, żołnierze i urzędnicy obozu w Auschwitz wysyłali do swoich domów w Rzeszy. Od razu należy zaznaczyć, że Autor włożył tu dużo pracy nie tylko jako naukowiec i analityk źródeł, ale również jako zbieracz i kolekcjoner. Nierzadko sam własnoręcznie zdobył trudno dostępne materiały, co pozwoliło mu na przeprowadzenie interpretacji nie tylko w sferze ikonograficznej, ale również materialnej. Jednym z takich artefaktów kulturowych są dla Małczyńskiego pocztówki: przedstawia ich spójną interpretację, wskazując na ich pseudo-obiektywizujące i niby-etnograficzne uwikłania z jednej strony, z drugiej zaś podejmuje ich temat jako przedmiotów, posiadających materialną strukturę wartą zauważenia. Jak zaznacza, „pocztówki przechowują w sobie ślady przeszłości" (Małczyński 93).

W rozdziale tym pojawia się ważne omówienie nazistowskich koncepcji krajobrazu i tego, jak wpłynęły one na Zagładę. W istotny sposób Autor podkreśla tutaj rolę robotników przymusowych i więźniów w kształtowaniu tego „idealnego" krajobrazu. Oprócz rozważań dotyczących wizji niemieckiego „Wschodu” jako kolonii, warto w tym rozdziale zwrócić uwagę także na aspekt przedstawiania tych przestrzeni jako pustych, „,ałkowicie niezbadanych” - jak pisał cytowany przez autora Günther Niethammer (Małczyński 78). Fotografia krajobrazowa służyła bowiem w gruncie rzeczy do utrwalania tylko pewnych, wybranych obrazów, na przykład przestrzeni bez jej mieszkańców (Małczyński 82-83) i komunikowania za pośrednictwem tych wyobrażeń określonych treści, nierzadko zideologizowanych. Jest zatem tylko pozornie obiektywna, tak jak pozornie obiektywna jest fotografia w ogóle (Sekula 6). Szkoda, że Autor nie poświęcił jeszcze więcej miejsca na pokazanie, w jaki sposób teorie te zyskiwały przerażające, materialne odbicie w miejscach takich jak obozy śmierci, bowiem fragmenty dotyczące związków między budową geologiczną terenu a położeniem obozu w Auschwitz (Małczyński 53-56) czy te omawiające ogród Rudolfa Hössa (Małczyński 7o) są jednymi z najciekawszych w tej części książki. Kontrast 
między bukolicznym obrazem „niemieckiego Wschodu”, po który wystarczy sięgnąć, a tym, co de facto przyniosła tym terenom nazistowska kolonizacja, wybrzmiałby wówczas jeszcze mocniej.

Rozdział drugi, zatytułowany Polityka natury w muzeach - miejscach pamięci Zagłady (w Auschwitz-Birkenau i Bełżcu), przybliża dwa wymienione w tytule przykłady podejścia do utrwalania pamięci o Zagładzie w muzeach znajdujących się na terenie dawnych obozów: w Auschwitz-Birkenau oraz w Bełżcu. Pierwsze z nich Autor wybrał, jak pisze, ze względu na jego ikoniczną rolę i status miejsca „paradygmatyczn[ego], metonimi[i] Zagłady” (Małczyński 96). Drugie ze względu na bycie zupełnym przeciwieństwem pierwszego: nie zachowały się tutaj ślady po obozie, zlikwidowanym w 1943 roku przez Niemców. Zestawienie tych dwóch miejsc jest bardzo ciekawym zabiegiem, który dodatkowo pozwala na powiedzenie czegoś nowego na temat przestrzeni, o których powiedziano już tak wiele, przez wydobycie kontrastów między nimi. Małczyńskiego zajmuje przede wszystkim waloryzacja krajobrazów obozowych w procesie ich krzepnięcia jako miejsc pamięci po 1945 roku, choć w przypadku obu obozów skrótowo przedstawia także ich wygląd i funkcjonowanie przed tą graniczną datą. W pierwszym wybranym przypadku Autor opisuje zatem rujnację obozu w Birkenau, „jego porzucenie i przekształcenie w miejsce porośnięte bujną roślinnością” (Małczyński 101), koleje losów Międzynarodowego Konkursu na Pomnik Ofiar Oświęcimskich w Brzezince, proces ustalania granic muzeum i sposoby zachowywania krajobrazu: ocenę „historyczności” roślinności i walkę z tą częścią flory, której takiego statusu odmówiono. W drugim wybranym przypadku Małczyński przechodzi od pierwszych relacji osób zdumionych, jak niewidoczne są ślady funkcjonowania obozu, przez prowadzone badania, po założenie pomnikowe, realizowane tu od 2002 roku. Opisawszy te dwa przypadki, przechodzi do części interpretacyjnej, gdzie je ze sobą zestawia. Uznając, że „sposób, w jaki jest kształtowany poobozowy krajobraz, nie pozostaje bez wpływu na kształt pamięci o wydarzeniach, które się w tym miejscu rozegrały" (Małczyński 125), i wychodząc od topologii miejsc odwiedzanych przez byłych więźniów (Cole 104-105), Autor wskazuje na to, jak idylliczna momentami przyroda wywołuje w zwiedzających dysonans poznawczy. Przywołuje tu także koncepcję powidoku Władysława Strzemińskiego, chcąc pokazać uparte trwanie pewnych zjawisk, pozbawionych już materialnego wsparcia (Małczyński 127). Interesuje go również muzealizacja obu miejsc, zwłaszcza tam, gdzie mamy do czynienia z próbami „zachowania bądź odtworzenia krajobrazu obozowego” (Małczyński 128), i związana z nią polityka natury: przede wszystkim dbanie o miejscową florę, które ma swoje janusowe oblicze. Z jednej strony bowiem chodzi tu o zachowanie różnie rozumianej „wierności historycznej”, z drugiej zaś 
mamy do czynienia z wyniszczaniem tej roślinności, która nie spełnia takiego standardu. Istotnym wątkiem, który pojawia się w tym rozdziale i będzie miał swoją kontynuację w rozdziale trzecim, jest także figura drzewa jako świadka zbrodni.

Rozdział trzeci, pod tytułem Krajobrazy Zagłady w sztuce współczesnej, jest omówieniem pięciu prac dwudziesto- i dwudziestopierwszowiecznych artystów: dzieł Winterreise Mirosława Bałki, Pomnik-Droga zespołu Oskara Hansena, Miejsce nieparzyste i Zielnik Elżbiety Janickiej oraz Berlin-Bikrenau Łukasza Surowca. Rozdział ten dobrze unaocznia problem, jaki przedstawiają sobą Krajobrazy Zagłady: czy ze względu na temat i wykorzystany materiał możliwe jest porównywanie ze sobą i zestawianie źródeł o różnej proweniencji, wydźwięku, powstałych w różnych okresach i kontekstach, w różnym celu i posiadających różne formy (materialne i niematerialne, a w przypadku pracy zespołu Hansena także: zrealizowane i niezrealizowane, mające jedynie wymiar konceptualny, ale zakorzeniony w tradycji myślenia o temacie)? Czy takie działanie jest możliwe bez uwzględnienia kontekstu, w którym funkcjonują poszczególne dzieła, i bez przedstawienia jasnego klucza doboru, który byłby czymś więcej niż podobienstwem tematycznym? Autor odnosi się tutaj do dzieł, które reprezentują, ale i - jak pisze - przekształcają krajobraz Zagłady (Małczyński 213). Małczyński polemizuje z poprzednimi interpretacjami omawianych prac, odwołuje się także do swoich wcześniejszych analiz, dotyczących przede wszystkim nazistowskiej ideologii odnoszącej się do natury. Stawia przy tym prowokujące pytania, takie jak na przykład, „czy naziści [...] nie patrzyliby na Winterreise [Mirosława Bałki] z zachwytem" (Małczyński 160). Ujawnia się tutaj jeden z mankamentów wywodu, w którym stawiane są wielkie pytania, dotykające nierzadko ciekawej strony problemu, a które traktuje się jako pytania retoryczne lub - pomimo obietnic - nie udziela na nie odpowiedzi.

W zakończeniu Autor pisze, że „przedstawione w tej książce analizy pokazują, że Zagłada Żydów podczas drugiej wojny światowej nie wydarzyła się w środowiskowej próżni” (Małczyński 211). To jeden z przykładów strategii pisarskiej Autora. Nie tyle jest to wniosek, który powinien znaleźć się w zwieńczeniu często interesujących - jak wskazywałam wyżej - analiz, ile raczej założenie, z którym od początku były prowadzone. Jak bowiem zauważała Susan Sontag, cytowana przez Autora, patrząc, zawsze coś się widzi (Małczyński 182). Podobnie jest ze zwieńczeniem wywodu, w którym Małczyński nadmienia, że „prowadzone w tej książce rozważania prowadzą do pytania o to, jaki krajobraz Zagłady pragniemy przekazać przyszłym pokoleniom" (Małczyński 214). Samo w sobie pytanie to jest zarówno ciekawe, jak i istotne, nurtuje mnie jednak coś innego: to przykład odkładania przez Autora odpowiedzi na pytania, które 
stawia przed czytelnikiem w całym tekście. Innym przykładem takiej tendencji jest końcówka rozdziału pierwszego, gdzie w miejscu wniosku Autor proponuje kolejną dalszą perspektywę: „biorąc pod uwagę znaczenie, jakie przypisywano w Trzeciej Rzeszy różnym formom krajobrazu, można się zastanawiać, czy druga wojna światowa nie stanowiła preludium do wojen klimatycznych" (Małczyński 95). Chcąc samej odpowiedzieć na różnorakie pytania, które czytelnik może znaleźć na stronach Krajobrazów Zagłady, zaczęłam się zastanawiać, czy analizy Małczyńskiego nie prowadzą do postawienia innych pytań niż te wyżej wymienione - i do udzielenia na nie odpowiedzi! - o podmiotowość i sprawczość czynników ludzkich i nie-ludzkich w przestrzeniach Zagłady i w ich reprezentacjach? Do pytania - i odpowiedzi - o zmianę zachodzącą w krajobrazach Zagłady? Autor wybiega w przyszłość, przedstawiając czytelnikowi nie tylko dalsze - kuszące, trudno tu odmówić Małczyńskiemu racji - pomysły badawcze. Zastanawiam się, czy nie jest to w ogóle problem pewnych gałęzi humanistyki, które w dążeniu do nowego przedstawiania problemów czasami gubią rzetelne skupienie się na danej problematyce. Nowoczesne imaginarium metodologiczne niekoniecznie musi tu zatem przemawiać na korzyść - nie musi jednak od razu, zaznaczam, być spisywane na straty jako „nowinka”. Problem ten jest szczególnie palący w przypadku kwestii wcześniej często podejmowanych i przykładów opisywanych przez poprzednie pokolenia badaczy. Wracając jednak do omawianej monografii: w Krajobrazach Zagłady Małczyński udowadnia, że umie się posługiwać narzędziami, które wybrał. Inną kwestią jest, że po prostu nie wszędzie się one sprawdzają.

Spróbujmy przyjrzeć się podtytułowi książki - sugeruje on bowiem bardzo precyzyjne ustawienie perspektywy metodologicznej przez samego Autora, skoro mowa jest o „perspektywie historii środowiskowej” - i nastręcza najwięcej bodaj problemów. Historia środowiskowa to termin, w którym odwołanie się do „środowiska” miało spowodować odsunięcie na dalszy plan sporu o to, czym jest „natura” (Praczyk 14-15, Izdebski 11-13). Naukowcy zajmujący się nią nie ukrywają, że istnieje silny wpływ człowieka na środowisko - ujawniający się na przykład w podejmowanych ciągle na nowo dyskusjach o relacjach pomiędzy „naturą” i „kulturą” - a myślenie o nietkniętych terenach globu jest spojrzeniem anachronicznym i bliższym dawniejszemu przekonaniu antropologów, że możliwe jest badanie wyizolowanych społeczności, na które nie mają wpływu czynniki pochodzące z „zewnątrz”. Małczyński definicję historii środowiskowej przytacza za J. Donaldem Hughesem, pisząc o niej jako o „rodzaj[u] historii, który próbuje zrozumieć to, jak istoty ludzkie żyły, działały i myślały w relacji do reszty natury poprzez zmiany następujące w czasie” (Małczyński 9). To skrótowe ustawienie optyki badawczej Autor doprecyzowuje, pisząc, o jaką 
„historię środowiskową” mu chodzi: o „historię środowiskową Zagłady”. Dyscyplina ta zyskała kształt stosunkowo niedawno - Małczyński odwołuje się tu do pracy Tima Cole'a z 2014 (Holocaust landscapes) i Geographies of the Holocaust z 2016 roku pod współredakcją tegoż autora, sygnalizując wcześniejsze podjęcia problemu w pracach takich historyków, jak chociażby Timothy Snyder (2015). Osadza również swoją pracę w polskim środowisku naukowym, wiążąc ją z badaniami prowadzonymi przez Ewę Domańską, Aleksandrę Ubertowską, Romę Sendykę, Mikołaja Smykowskiego i Agnieszkę Kłos, a także Piotra Krupińskiego i środowisko „Tekstów Drugich” (Małczyński 15-16). Zauważa, że: „bada [ona] relacje zachodzące w środowisku między czynnikami ludzkimi a nie-ludzkimi (np. roślinami, zwierzętami, klimatem, pogodą, ukształtowaniem terenu, zarazkami, itd.)" (Małczyński 9). Zakreśla trzy pola, jakie te badania obejmują: (1) wpływ środowiska na przebieg Zagłady (np. lokalizacja obozów w określonych warunkach naturalnych), (2) wpływ Zagłady na środowisko (np. wpływ funkcjonowania obozów na środowisko) oraz (3) „wyobrażenia, znaczenia i wartości związane z przyrodą w kontekście Zagłady" (Małczyński 9) (np. przedstawienia przyrody w relacjach ocalałych, ideologizacja przyrody w polityce Trzeciej Rzeszy, reprezentacja Zagłady pod kątem krajobrazu w sztuce).

Chociaż Autor początkowo szeroko kreśli zamiary, jakie stawia przed sobą w omawianej monografii, nie sposób oprzeć się wrażeniu, że koniec końców interesuje go przede wszystkim - do czego sam się zresztą explicite przyznaje (Małczyński 10) - to trzecie z wymienionych pól. A zatem to, co bada, to pewne kulturowe reprezentacje. Krajobrazy Zagłady sytuowałby się zatem w tym polu badawczym, które za poznańską historyczką środowiskową Małgorzatą Praczyk można nazwać „historią wyobrażeń o środowisku przyrodniczym” (Praczyk 25). Pojawia się tutaj jednak pierwsze pytanie: czy faktycznie taki jest cel - i do tego zmierza analiza - Autora omawianej książki? Praczyk konstatuje, że istnieje jeszcze jeden nurt w historii środowiskowej, który polega na badaniu „konkretnej rzeczywistości historycznej”, w którym „powstawały i powstają prace prezentujące badania nad przekształceniami, które pod wpływem człowieka dokonały się w środowisku przyrodniczym, oraz nad tym, jak przyroda zwrotnie wpływała na bieg ludzkich dziejów" (Praczyk 25). Co zatem właściwie chce badać i co bada Małczyński: wyobrażenia o krajobrazie czy też krajobrazy? Odpowiedzi na to pytanie nie ułatwia rodzaj źródeł, jakie wybiera Autor. Wydaje się, że wybór jednego spójnego mianownika, który pozwoliłby na jednolitą lekturę Krajobrazów Zagłady, jest z racji jej kompozycji zasadniczo niemożliwy.

Drugie pytanie, nad którym może głowić się czytelnik tej książki, również dotyka delikatnej materii dyscypliny, w ramach której chce poruszać się Autor. Jak sam zaznacza, wybór historii środowiskowej to zarazem wybór wielody- 
scyplinarności, bowiem „splata [ona, tj. historia środowiskowa] ze sobą wątki z zakresu geologii, archeologii, geografii, biologii, ekologii, historii, socjologii, literaturoznawstwa, kulturoznawstwa i innych dziedzin wiedzy” (Małczyński 9). Takie postawienie sprawy nie ułatwia odbiorcy zadania, działa również na niekorzyść Autora, który nie omawia tego, co właściwie przejmuje z poszczególnych dyscyplin, przez co Krajobrazy Zagłady używają kategorii interdyscyplinarności bardziej jako użytecznego wytrychu, nie problematyzując chociażby tego, w jaki sposób dana dyscyplina podchodzi do przeszłości jako przedmiotu swoich badań (Izdebski 68) czy w jaki sposób - o ile w ogóle - bada reprezentacje. Być może bardziej adekwatne byłoby zastanowienie się nad jeszcze szerszą kategorią badawczą, jaką mogłaby być humanistyka środowiskowa - obszar zainteresowań, na który Autor wskazuje w swoim biogramie - co pozwoliłoby, paradoksalnie, na bardziej precyzyjne określenie narzędzi badawczych, a zarazem rozwiązałoby początkowe kłopoty czytelnika. Po lekturze Krajobrazów Zagłady można bowiem mieć całkiem uzasadnione wątpliwości, czy faktycznie mamy do czynienia z monografią pisaną z perspektywy historii środowiskowej.

Rozwiązaniem mogłoby być także konsekwentne przyjęcie przez Małczyńskiego punktu widzenia brytyjskiego antropologa Tima Ingolda, który zaznaczał, że „historia środowiskowa jest historią działań wszystkich organizmów - ludzkich i nieludzkich, współczesnych i przeszłych”, z której wynika również porównanie środowiska do „rzeźby lub pomnika, z uwzględnieniem dwóch okoliczności: po pierwsze, środowisko nie jest kształtowane ręką jednego twórcy, lecz wielu; po drugie, akt twórczy nigdy się nie kończy” (Ingold 83). Małczyński włącza tę definicję do swojego repertuaru teoretycznego, nie używa jej jednak od początku do końca. Sygnalizuje - jak w przypadku przywołanego wyżej fragmentu z Ingolda - podążanie pewnym szlakiem, porzuca go jednak na czas dłuższy, by dopiero za jakiś czas nań wrócić. Tak jak wtedy, gdy powraca do myśli o środowisku jako pomniku i w zakończeniu rozdziału poświęconego muzeom-miejscom pamięci proponuje odwrócić to porównanie. Jak pisze, warto porównać pomnik do środowiska, co z kolei pozwoliłoby patrzeć na pomnik nie tylko jako na „martwą materię”, ale na środowisko, które podlega ciągłym przekształceniom ze strony tak czynników ludzkich, jak i nie-ludzkich (Małczyński 143). Tutaj jednak ponownie pojawia się problem z różnorodnością źródeł, na podstawie których Autor buduje swoją opowieść o krajobrazach Zagłady.

Spróbujmy przyjrzeć się temu bliżej. Polifonia bowiem, do jakiej może prowadzić wybór wielu różnorodnych źródeł, niesie ze sobą niebezpieczeństwo bałaganu. Autor zaznacza, że interesuje go "opis gęsty” z tradycji Clifforda Geertza, ale oparty o szczegółowe studium przypadku (Małczyński 16). Studia te są wynikiem kwerend Autora, prowadzonych w poszukiwaniu materia- 
łów niewykorzystywanych dotychczas w badaniach. W pierwszym rozdziale głównym źródłem są - jak już wspominałam wyżej - niemieckie pocztówki, wysyłane z Auschwitz, malarstwo krajobrazowe (obrazy Gerharda Fritza Hensela ${ }^{1}$, szwagra komendanta obozu Rudolfa Hössa, i Władysława Siwka, więźnia obozu) oraz wykorzystane przy produkcji pocztówek „dokumentacyjne” zdjęcia Oświęcimia i okolic $\mathrm{z}$ lat czterdziestych $\mathrm{xx}$ wieku, znajdujące się w zbiorach Instytutu Yad Vashem. Małczyński pisze tu o obiektach, które podlegały swoistej muzealizacji jeszcze w trakcie działania obozu: powstając na zlecenie esesmanów, miały pokazywać ciekawostki i kurioza z okolicy o charakterze „etnograficznym” czy „przyrodniczym”. W tym duchu Małczyński przywołuje też artykuł ornitologiczny Günthera Niethammera Obserwacje ptaków w Auschwitz. Nie widać jednak nawiązania pomiędzy tak szeroko rozpostartym przed czytelnikiem zakresem analizowanych artefaktów tutaj i w dalszej części książki - gdzie Małczyński nieco bardziej szczegółowo wraca do koncepcji muzealizacji i gdzie taka nić łącząca te pola mogłaby być przydatnym, porządkującym tekst narzędziem.

To bogactwo materiału przywołanego w rozdziale pierwszym ustępuje pola nieco innemu podejściu już w rozdziale drugim. Głównymi materiałami poddawanymi analizie są $\mathrm{w}$ nim przestrzenie muzeów Zagłady na terenie dawnych obozów Auschwitz-Birkenau oraz Bełżec oraz prowadzona w nich polityka: z jednej strony muzealizacji obiektów i przedmiotów, z drugiej natury i jej roli w tak określonym wariancie upamiętnienia, co sam autor nazywa związkami między polityką pamięci a polityką natury (Małczyński 212). Najspójniejszy pod względem źródeł jest tu rozdział trzeci, gdzie omawiane są prace artystów tworzących zarówno współcześnie (Mirosław Bałka, Elżbieta Janicka, Łukasz Surowiec), jak i w przeszłości (zespół Oskara Hansena). Być może jest to dowód na to, że Autor najswobodniej czuje się faktycznie w analizie reprezentacji i w trzecim z wymienionych przez siebie pól badania historii środowiskowej Zagłady. Tym większa szkoda, że nie przeprowadził w tekście wewnętrznych ram porządkujących zebrane materiały, by pokazać, w jakim stopniu każdy z analizowanych przypadków dotyczy przede wszystkim reprezentacji. Można wyczytać pomiędzy wierszami, na korzyść Autora, taką linię interpretacyjną można ją jednak było wyartykułować wprost.

1 Autor na s. 16 nazywa go omyłkowo Hansem, na s. 73 zaś już prawidłowo Gerhardem. Zapisuje również to nazwisko konsekwentnie jako „Henzel” zamiast „Hensel”. $\mathrm{Z}$ innych tego typu omyłek czytelnika może również zdziwić drabina ze snu Dawida, pojawiająca się na s. 123. Zakładam, że Autorowi chodziło o drabinę ze snu innego biblijnego protoplasty, Jakuba. 
W książce pojawia się więcej takich ukrytych założeń. Jak właściwie Małczyński rozumie „krajobraz”? Czym on dla niego jest? Czytelnik może co prawda wywnioskować z tekstu, że Autorowi chodzi przede wszystkim o krajobraz przetworzony przez działania człowieka - w który nierzadko później powracała z całą mocą natura - niemniej bez przydatnych przymiotników go określających, jak pisał kiedyś Stanisław Pietraszko (Pietraszko 57), może to prowadzić do pewnej konfuzji. Poruszenie problemu różnego podejścia do natury i ludzkiego do niej stosunku w dyskursie oświeceniowym i romantycznym (Małczyński 218) powinno też prowadzić do bardziej zniuansowanych pytań o ambiwalencje w „narodowych” - a może nawet jeszcze bardziej: „lokalnych” - reprezentacjach natury i tego, czemu służyły. Innym problemem, jaki stwarzają analizy Małczyńskiego, jest perspektywa, z jakiej są prowadzone. Na ile uwzględniają biernego widza czy też obserwatora, na ile czynnie działający podmiot? Gdzie, w przypadku na przykład wspomnień dawnych więźniów obozu wracających do miejsca kaźni, przebiega taka granica i czy w ogóle można ją wyznaczyć? Próba odpowiedzi na pytanie o to, w jaki sposób pamięć ciąży na wszystkich czynnikach procesu pamiętania - sformułowana przez Autora przy okazji analizy dzieła Bałki (Małczyński 154) - mogłaby powiązać i uspójnić poszczególne części.

Czytelnik jest w stanie zauważyć, że Autor umie przekonująco uargumentować swoje stanowisko oraz odpowiedzieć na stawiane pytania, proponując przy tym ciekawe spojrzenie na - niekiedy wydawałoby się, że aż za dobrze znany - problem. Na uwagę zasługują na przykład analizy drzew jako świadków - obserwujących, ale nie komunikujących (Małczyński 133). Może warto byłoby odwołać się tutaj do rozważań Elżbiety Janickiej na temat „świadka” jako kategorii w temacie poruszanym przez Autora (Janicka 148-227)? Badaczkę tę Małczyński przywołuje tylko jako twórczynię dwóch analizowanych przez siebie dzieł w rozdziale trzecim, a warto pamiętać, że jest to również autorka naukowych tekstów na temat Zagłady.

Jak już wspominałam, wiele kategorii, które przywołuje Małczyński, jest inspirujących i szkoda, że Autor nie zawsze pracuje z nimi dalej. Chociażby „powidok”, używany za Strzemińskim, mógłby stać się kategorią bardzo cielesną, materialną - dotyczy wszak zmysłu wzroku i budowy oka. Wymagałoby to jednak skupienia się przez Autora na jednym wymiarze analizowanych zjawisk - prowadziłoby to do dalszego namysłu nad przywoływanymi zjawiskami i mogłoby skutkować odpowiedziami zamiast stawiania dalszych, coraz bardziej rosnących w skali, pytań. Podobnie jest z uwagą dotyczącą sztuki współczesnej jako próby odwrócenia krajobrazu, zobaczenia, co jest pod spodem, i czy da się to wydobyć na zewnątrz (Małczyński 175). Warto byłoby z pewnością dalej eksplorować ten problem, zwłaszcza że Autor zgadza się z uwagą Ewy Domańskiej, 
że często to sztuka znacznie bardziej niż humanistyka skłania do zadawania pytań (Małczyński 207). Dodałabym: i poszukiwania odpowiedzi na nie. Autor bowiem umie stawiać pytania, nierzadko interesujące, o czym czytelnik może się dobitnie przekonać - ma jednak problem $\mathrm{z}$ udzielaniem na nie odpowiedzi.

Na koniec pozostaje, by nie być gołosłowną, odpowiedzieć na pytanie, czy deklarowany na samym początku Krajobrazów Zagłady przez Autora cel - „włączenie [się] w [...] debaty na temat zmian klimatu, zrównoważonego rozwoju, wymierania gatunków, klęsk ekologicznych czy związanych z tym migracji klimatycznych" został spełniony? Moja odpowiedź brzmi: nie. Nie dlatego, że Autor nie ma interesujących przemyśleń, ale kompozycja książki, panujący w niej redakcyjny chaos i wyrastające nad horyzontem odpowiedzi na coraz to nowe pytania sprawiają, że trudno jest uplasować tę książkę tam, gdzie, zdaje się, Autor chciał ją widzieć. Nie oznacza to bynajmniej, że czas poświęcony na jej lekturę jest stracony - najciekawsza jest ona jednak tam, gdzie Autor omawia reprezentacje, pokazując ich wywrotową niekiedy siłę, najsłabsza zaś tam, gdzie poza to pole próbuje wyjść.

\section{| Bibliografia}

Cole, Tim. „Crematoria, barracks, gateway. Survivors' return visit to the memory landscape of Auschwitz". History \& Memory 25.2 (2013). S. 102-131.

Ingold, Tim. „Kultura i postrzeganie środowiska”. Badanie kultury. Elementy teorii antropologicznej. Red. M. Kempny, E. Nowicka. Warszawa: PWN, 2005. S. 73-86.

Izdebski, Adam. „Konwergencja nauk przyrodniczych i historycznych: teoretyczny potencjał i praktyczne trudności”. Historyka. Studia Metodologiczne 44 (2014). S. 67-93.

Janicka, Elżbieta. „Pamięć przyswojona. Koncepcja polskiego doświadczenia zagłady Żydów jako traumy zbiorowej w świetle rewizji kategorii świadka”. Studia Litteraria et Historica 3-4 (2015). S. 148-227.

Pietraszko, Stanisław. „Krajobraz i kultura”. Krajobrazy. Antologia tekstów. Red. D. Angutek, B. Frydryczak. Poznań: Wydawnictwo Poznańskiego Towarzystwa Przyjaciół Nauk, 2014. S. 55-62.

Praczyk, Małgorzata. Pamięć środowiskowa we wspomnieniach osadników na „Ziemiach Odzyskanych”. Poznań: Wydawnictwo Instytutu Historii UAM, 2018. Sekula, Allan. „The Body and the Archive”. October 39 (1986). S. 3-64. Snyder, Timothy. Czarna ziemia. Holocaust jako ostrzeżenie, Kraków: Znak Horyzont, 2015. 


\section{| Nota o autorze}

Karolina Ćwiek-Rogalska - kulturoznawczyni i etnolożka, pracuje jako adiunktka w Instytucie Slawistyki PAN w Warszawie. Autorka monografii Zapamiętane w krajobrazie. Krajobraz kulturowy czesko-niemieckiego pogranicza w czasach przemian (Scholar 2017). W swoich badaniach podejmuje tematy związane z wpływem wysiedleń społeczności niemieckojęzycznych z Czech, Słowacji i Polski po roku 1945 z perspektywy antropologii krajobrazu i badań nad kulturą materialną.

E-mail: karolina.rogalska@ispan.waw.pl 
